\title{
Assessment of a Physicochemical Indexing Method for Evaluation of Tropical River Water Quality
}

\author{
Siong Fong Sim (i) and Szewei Elaine Tai (i) \\ Faculty of Resource Science \& Technology, Universiti Malaysia Sarawak, 94300 Kota Samarahan, Sarawak, Malaysia \\ Correspondence should be addressed to Siong Fong Sim; sfsim@unimas.my
}

Received 29 June 2017; Accepted 4 December 2017; Published 8 January 2018

Academic Editor: Samuel B. Dampare

Copyright (c) 2018 Siong Fong Sim and Szewei Elaine Tai. This is an open access article distributed under the Creative Commons Attribution License, which permits unrestricted use, distribution, and reproduction in any medium, provided the original work is properly cited.

\begin{abstract}
This paper attempts to evaluate the Malaysian water quality indexing method that has been criticized for its ineffectiveness. The indexing method is referred to as the Water Quality Index of the Department of Environment, Malaysia (DOE-WQI). This index was assessed against two other indices (River Ganga Index and Minimal Water Quality Index (WQI min $)$ ) and a modified DOE-WQI was also proposed. DOE-WQI and $\mathrm{WQI}_{\min }$ are physicochemical indices, whereas the River Ganga Index and modified DOE-WQI are indices with the inclusion of a microbiological parameter. The assessment was conducted based on the water quality of tropical rivers in Malaysia, with specific reference to Sarawak River and its tributaries. Water quality in terms of $\mathrm{pH}$, dissolved oxygen, conductivity, turbidity, total suspended solids, biochemical oxygen demand, chemical oxygen demand, ammoniacal nitrogen, and fecal coliform count (FCC) was measured from 18 stations in December 2015, January 2016, and March 2016. Generally, the river was characterized with high FCC with the four indices significantly correlated. The results demonstrated the shortcomings of the existing DOE-WQI; the physicochemical index assigned water quality to a better class than its actual conditions without taking into consideration the FCC.
\end{abstract}

\section{Introduction}

Water quality monitoring is an area of utmost concern for many developing countries due to the rapid growth in population and urbanization. In Malaysia, many river catchments are at risk as a result of increasing land use. As reported by the Department of Environment (2010) [1], the percentage of clean river basins has consistently reduced with increasing numbers of rivers categorized as moderately polluted/ polluted. The water quality of Malaysian rivers is primarily monitored based on the water quality index (WQI) developed by the Department of Environment using six physicochemical parameters, namely, dissolved oxygen (DO), biochemical oxygen demand (BOD), chemical oxygen demand (COD), ammoniacal nitrogen $\left(\mathrm{NH}_{3}-\mathrm{N}\right)$, total suspended solids (TSS), and $\mathrm{pH}$. This approach, like other water quality indices, transforms the water quality data into a single numerical value to depict the overall water quality with a score between 0 and $100[2,3]$. It has been widely used to facilitate the decision-making process and management of regulatory programs relating to water quality assessment in Malaysia.

Numerous water quality indexing methods were developed for different uses and water sources; the first water quality index was introduced in 1965 [4]. They differ primarily in the determinants used, the mathematical derivation strategies, and the classification criteria [2]. This has been comprehensively reviewed by Gitau et al. [5]; for example, the water quality index of the U.S. National Sanitation Foundation (NSF) uses nine variables, that is, DO, fecal coliform count (FCC), $\mathrm{pH}$, biochemical oxygen demand (BOD), temperature (Temp), total phosphate (TP), nitrate $\left(\mathrm{NO}_{3}{ }^{-}\right)$, turbidity (Turb), and total solids (TS). For each parameter, a score, $Q_{n}$, is determined from a rating curve and multiplied by the weightage assigned, $W_{n}$, yielding the weighted subindices. The sum of the weighted subindices describes the water quality status where a score of $90-100$ denotes excellent water quality whereas a score of 70-90 indicates water in good condition $\left[\sum_{n=1}^{N} Q_{n} W_{n}\right.$ ( $n$ is the determinant involved)]. A lower score of $50-70,25-50$, and 0-25 refers to medium, 
TABLE 1: The GPS coordinates of the sampling stations.

\begin{tabular}{|c|c|c|c|}
\hline River & Station & GPS coordinates & Description \\
\hline \multirow{3}{*}{ Sarawak Kanan } & 1 & $1^{\circ} 23^{\prime} 51.8^{\prime \prime} \mathrm{N}, 110^{\circ} 06^{\prime} 59.4^{\prime \prime} \mathrm{E}$ & At the bridge near Ruiz Suba Buan Village \\
\hline & 2 & $1^{\circ} 24^{\prime} 54.5^{\prime \prime} \mathrm{N}, 110^{\circ} 08^{\prime} 06.1^{\prime \prime} \mathrm{E}$ & Wind Cave \\
\hline & 3 & $1^{\circ} 25^{\prime} 25.2^{\prime \prime} \mathrm{N}, 110^{\circ} 09^{\prime} 00.5^{\prime \prime} \mathrm{E}$ & At the bridge near Bau Water Treatment Plant \\
\hline \multirow{2}{*}{ Sarawak Kanan } & 4 & $1^{\circ} 27^{\prime} 08.0^{\prime \prime} \mathrm{N}, 110^{\circ} 11^{\prime} 02.1^{\prime \prime} \mathrm{E}$ & At Buso Village \\
\hline & 5 & $1^{\circ} 26^{\prime} 50.1^{\prime \prime} \mathrm{N}, 110^{\circ} 13^{\prime} 10.7^{\prime \prime} \mathrm{E}$ & At Siniawan Village \\
\hline \multirow{2}{*}{ Sarawak Kiri } & 6 & $1^{\circ} 27^{\prime} 07.5^{\prime \prime} \mathrm{N}, 110^{\circ} 16^{\prime} 54.6^{\prime \prime} \mathrm{E}$ & At Bau Bridge Road \\
\hline & 7 & $1^{\circ} 27^{\prime} 03.8^{\prime \prime} \mathrm{N}, 110^{\circ} 16^{\prime} 52.8^{\prime \prime} \mathrm{E}$ & Near Sk. Batu Kitang and village \\
\hline \multirow{2}{*}{ Sarawak } & 8 & $1^{\circ} 30^{\prime} 01.0^{\prime \prime} \mathrm{N}, 110^{\circ} 14^{\prime} 47.0^{\prime \prime} \mathrm{E}$ & At the bridge of Batu Kawa Road \\
\hline & 9 & $1^{\circ} 32^{\prime} 22.4^{\prime \prime} \mathrm{N}, 110^{\circ} 17^{\prime} 09.9^{\prime \prime} \mathrm{E}$ & At Sejijak Village \\
\hline \multirow{3}{*}{ Maong } & 10 & $1^{\circ} 32^{\prime} 34.0^{\prime \prime} \mathrm{N}, 110^{\circ} 18^{\prime} 40.2^{\prime \prime} \mathrm{E}$ & At Maong River Village with construction activities \\
\hline & 11 & $1^{\circ} 32^{\prime} 00.5^{\prime \prime} \mathrm{N}, 110^{\circ} 19^{\prime} 27.3^{\prime \prime} \mathrm{E}$ & Near housing areas \& primary schools \\
\hline & 12 & $1^{\circ} 31^{\prime} 35.0^{\prime \prime} \mathrm{N}, 110^{\circ} 20^{\prime} 12.0^{\prime \prime} \mathrm{E}$ & Near commercial areas \\
\hline \multirow{3}{*}{ Sarawak } & 13 & $1^{\circ} 33^{\prime} 17.0^{\prime \prime} \mathrm{N}, 110^{\circ} 19^{\prime} 25.8^{\prime \prime} \mathrm{E}$ & Near Satok Bridge \\
\hline & 14 & $1^{\circ} 33^{\prime} 36.6^{\prime \prime} \mathrm{N}, 110^{\circ} 20^{\prime} 46.4^{\prime \prime} \mathrm{E}$ & Kuching Waterfront Bazaar \\
\hline & 15 & $1^{\circ} 33^{\prime} 27.0^{\prime \prime} \mathrm{N}, 110^{\circ} 22^{\prime} 50.0^{\prime \prime} \mathrm{E}$ & Pending-Petra Jaya Toll Bridge, industrial area \\
\hline \multirow{3}{*}{ Sarawak } & 16 & $1^{\circ} 34^{\prime} 33.2^{\prime \prime} \mathrm{N}, 110^{\circ} 24^{\prime} 33.2^{\prime \prime} \mathrm{E}$ & Downstream of Sarawak Barrage \\
\hline & 17 & $1^{\circ} 34^{\prime} 31.2^{\prime \prime} \mathrm{N}, 110^{\circ} 24^{\prime} 36.9^{\prime \prime} \mathrm{E}$ & $\begin{array}{l}\text { Upstream of Sarawak Barrage, before discharge from any } \\
\text { industries }\end{array}$ \\
\hline & 18 & $1^{\circ} 32^{\prime} 38.7^{\prime \prime} \mathrm{N}, 110^{\circ} 23^{\prime} 21.9^{\prime \prime} \mathrm{E}$ & At the bridge at Setia Raja Road \\
\hline
\end{tabular}

bad, and very bad water quality, respectively $[2,6]$. The Oregon Water Quality Index (OWQI) on the other hand adopts eight parameters of NSF except Turb $[2,4]$. There are also indices derived using less than a handful of parameters which are cost-effective and useful for developing countries with a limited budget for water quality assessment [7]. A simple index with three key parameters of DO, BOD, and $\mathrm{NH}_{3}-\mathrm{N}$ was used to evaluate the level of organic pollution by the Environmental Protection Department, Hong Kong [8]. Simões et al. [9] employed total phosphorus, Turb, and DO to infer the effects of aquaculture activities on water quality.

The Malaysian Water Quality Index of six variables has been continuously reported with limitations; it is perceived as insufficiently inclusive as only physicochemical parameters are considered [10]. Al-Manun and Idris [11] suggested the addition of biological indicators to the existing index as microbial pollution is a widespread issue in rivers of Malaysia due to the warm and humid tropical climate, conducive for microbial growth [12-15]. Naubi et al. [16] examined the water quality of a Malaysian river, concluding that the existing WQI is not an effective measure as the index did not take into account heavy metals, nutrients, and FCC that are found to be problematic. Al-Manun and Idris [11] proposed a revisited version of DOE-WQI with turbidity and total phosphorus replacing $\mathrm{pH}$ and COD; the revised WQI was found to produce a score 10-20 points lower than the original index. Despite criticisms and recommendations, there are yet limited studies to objectively demonstrate the shortcomings

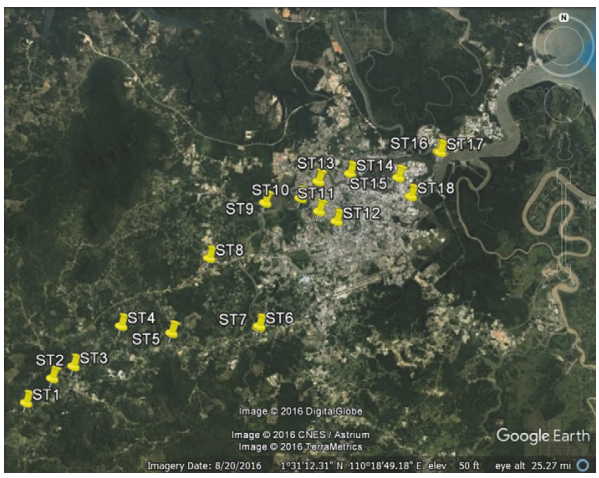

FIgURE 1: The sampling locations at the Sarawak River and its tributaries.

of this indexing method. Hence, this paper attempts to evaluate the effectiveness of Malaysian physicochemical WQI by comparisons with other indices and to propose a modified index for assessment of tropical rivers with specific reference to rivers in Sarawak, Malaysia.

\section{Materials and Methods}

2.1. Sampling. Water samples were collected from 18 stations located at the Sarawak River and its tributaries. The sampling stations are shown in Figure 1 with the corresponding GPS positions summarized in Table 1. Sampling was carried out 
during the wet season in December 2015, January 2016, and March 2016. The samples were collected from subsurface of $0-20 \mathrm{~cm}$ into $2 \mathrm{~L}$ polyethylene bottles for ex situ analyses including TSS, COD, and $\mathrm{NH}_{3}-\mathrm{N}$. No acid was added for preservation; the samples were analyzed within three days. For BOD analysis, the water samples were collected in a $2 \mathrm{~L}$ polyethylene bottle and shaken vigorously. The initial DO reading was recorded. The water sample was then filled into a $300 \mathrm{~mL}$ BOD glass bottle and wrapped with aluminum foil. For FCC analysis, water samples were collected in sterilized glass bottles and the analysis was conducted within 24 hours. All the samples were kept in the cooler box for transportation to the laboratory.

2.2. Water Quality Analyses. The in situ parameters including $\mathrm{pH}, \mathrm{DO}$, specific conductivity (Cond), and turbidity (Turb) were recorded using Horiba U-52 Multiparameter in triplicate. The meters were calibrated according to the standard procedures prior to sampling. The samples were subjected to ex situ analysis for TSS, BOD, $\mathrm{COD}, \mathrm{NH}_{3}-\mathrm{N}$, and FCC. Total suspended solids (TSS) were determined according to the standard method of gravimetric analysis [17]. A total of $500 \mathrm{~mL}$ of the water sample was filtered through a membrane filter of $0.45 \mu \mathrm{m}$. The membrane filter was preweighed to $0.1 \mathrm{mg}$. After filtration, the membrane filter was oven-dried at $105^{\circ} \mathrm{C}$ overnight and left to cool in a desiccator before its final weight was recorded. Biochemical oxygen demand (BOD) was determined according to the standard method of 5-day BOD test [17]. The BOD bottles were stored in the dark and the DO reading was recorded after 5 days. COD and $\mathrm{NH}_{3}-\mathrm{N}$ were measured using DR900 according to the reactor digestion method and salicylate method, respectively. Fecal coliform count (FCC) was determined based on the membrane filtration method.

2.3. Evaluation of Water Quality Indices. The water quality data obtained was evaluated with the water quality indexing method developed by the Department of Environment (DOE), Malaysia, referred to as DOE-WQI. The data was also subjected to evaluation with the River Ganga Index, Minimal Water Quality Index (WQI $I_{\min }$ ), and an index modified from the existing DOE-WQI (modified DOE-WQI), proposed by the authors.

2.3.1. Department of Environment Water Quality Index (DOEWQI) [1]. DOE-WQI is the sum of weighted subindices for six variables ( $\mathrm{pH}, \mathrm{DO}, \mathrm{BOD}, \mathrm{COD}, \mathrm{NH}_{3}-\mathrm{N}$, and TSS). The subindices are derived based on segmented nonlinear functions as follows.

DO (in \% saturation):

$$
\begin{aligned}
& \mathrm{SI}_{\mathrm{DO}}=0, \quad x \leq 8, \\
& \mathrm{SI}_{\mathrm{DO}}=100, \quad x \geq 92, \\
& \mathrm{SI}_{\mathrm{DO}}=-0.395+0.030 x^{2}-0.00020 x^{3}, \quad 8<x<92 .
\end{aligned}
$$

$B O D(m g / L):$

$$
\begin{aligned}
& \mathrm{SI}_{\mathrm{BOD}}=100.4-4.23 x, \quad x \leq 5, \\
& \mathrm{SI}_{\mathrm{BOD}}=108 e^{(-0.055 x)}-0.1 x, \quad x>5 .
\end{aligned}
$$

$\operatorname{COD}(m g / L):$

$$
\begin{aligned}
& \mathrm{SI}_{\mathrm{COD}}=-1.33 x+99.1, \quad x \leq 20, \\
& \mathrm{SI}_{\mathrm{COD}}=103 e^{(-0.0157 x)}-0.04 x, \quad x>20 .
\end{aligned}
$$

$$
\begin{aligned}
\mathrm{NH}_{3}-\mathrm{N}(m g / L) & : \\
\mathrm{SI}_{\mathrm{NH} 3-\mathrm{N}} & =100.5-105 x, \quad x \leq 0.3, \\
\mathrm{SI}_{\mathrm{NH} 3-\mathrm{N}} & =94 e^{(-0.573 x)}-5|x-2|, \quad 0.3<x<4, \\
\mathrm{SI}_{\mathrm{NH} 3-\mathrm{N}} & =0, \quad x \geq 4 .
\end{aligned}
$$

$\operatorname{TSS}(m g / L):$

$$
\begin{aligned}
& \mathrm{SI}_{\mathrm{SS}}=97.5 e^{(-0.00676 x)}+0.05 x, \quad x \leq 100 \\
& \mathrm{SI}_{\mathrm{SS}}=71 e^{(-0.0061 x)}-0.015 x, \quad 100<x<1000 \\
& \mathrm{SI}_{\mathrm{SS}}=0, \quad x \geq 1000
\end{aligned}
$$

pH:

$$
\begin{array}{ll}
\mathrm{Sl}_{\mathrm{pH}}=17.02-17.2 x+5.02 x^{2}, & x<5.5, \\
\mathrm{Sl}_{\mathrm{pH}}=-242+95.5 x-6.67 x^{2}, & 5.5 \leq x<7, \\
\mathrm{Sl}_{\mathrm{pH}}=-181+82.4 x-6.05 x^{2}, & 7 \leq x<8.75, \\
\mathrm{Sl}_{\mathrm{pH}}=536-77.0 x+2.76 x^{2}, & x \geq 8.75 .
\end{array}
$$

The sum of the weighted subindices is a score between 0 and 100 that is categorized into five classes (I-V) to suggest the beneficial uses of water.

$$
\begin{aligned}
\text { DOE-WQI }= & \left(0.22 \times \mathrm{SI}_{\mathrm{DO}}\right)+\left(0.19 \times \mathrm{SI}_{\mathrm{BOD}}\right) \\
& +\left(0.16 \times \mathrm{SI}_{\mathrm{COD}}\right)+\left(0.15 \times \mathrm{SI}_{\mathrm{NH} 3-\mathrm{N}}\right) \\
& +\left(0.16 \times \mathrm{SI}_{\mathrm{TSS}}\right)+\left(0.12 \times \mathrm{SI}_{\mathrm{pH}}\right) .
\end{aligned}
$$

Class I ( $>92.7)$ : conservation of natural environment; Water Supply 1, practically no treatment necessary; Fishery 1 , very sensitive aquatic species.

Class II (76.5-92.7): Water Supply II, conventional treatment required; Fishery II, sensitive aquatic species.

Class III (51.9-76.5): Water Supply III, extensive treatment required; Fishery III, common and tolerant species; for livestock drinking. 
TABLE 2: Values of parameters after normalization for WQI $\mathrm{min}_{\text {in }}$ (Pesce and Wunderlin, 2000).

\begin{tabular}{|c|c|c|c|c|c|c|c|c|c|c|c|}
\hline \multirow{3}{*}{ Class } & \multicolumn{11}{|c|}{ Normalization factor $(\mathrm{C} i)$} \\
\hline & \multicolumn{2}{|c|}{ I } & \multicolumn{2}{|c|}{ II } & \multicolumn{2}{|c|}{ III } & \multicolumn{2}{|c|}{ IV } & \multicolumn{3}{|c|}{$\mathrm{V}$} \\
\hline & 100 & 90 & 80 & 70 & 60 & 50 & 40 & 30 & 20 & 10 & 0 \\
\hline Cond $(\mu \mathrm{S} / \mathrm{cm})$ & $<750$ & $<1000$ & $<1250$ & $<1500$ & $<2000$ & $<2500$ & $<3000$ & $<5000$ & $<8000$ & $\leq 12,000$ & $>12,000$ \\
\hline $\mathrm{DO}(\mathrm{mg} / \mathrm{L})$ & $\geq 7.5$ & $>7.0$ & $>6.5$ & $>6.0$ & $>5.0$ & $>4.0$ & $>3.5$ & $>3.0$ & $>2.0$ & $\geq 1.0$ & $<1.0$ \\
\hline Turb (NTU) & $<5$ & $<10$ & $<15$ & $<20$ & $<25$ & $<30$ & $<40$ & $<60$ & $<80$ & $\leq 100$ & $>100$ \\
\hline
\end{tabular}

Class IV (31.0-51.9): irrigation.

Class V (<31.0): none of the above.

2.3.2. The River Ganga Index [2]. The River Ganga Index, like DOE-WQI, is a weighted arithmetic index. It is calculated based on four variables, namely, DO, FCC, $\mathrm{pH}$, and BOD. The subindices are derived according to the following equations with the ultimate score representing four classes [63-100: Class I (good-excellent/nonpolluted); 50-63: Class II (medium-good/nonpolluted); 38-50: Class III (bad/polluted); and <38: Class IV (bad-very bad/heavily polluted)]. Bhutiani et al. [18] employed this index to assess the water quality of the River Ganga from 2000 to 2010.

The River Ganga Index

$$
\begin{aligned}
= & \left(0.31 \times \mathrm{SI}_{\mathrm{DO}}\right)+\left(0.19 \times \mathrm{SI}_{\mathrm{BOD}}\right)+\left(0.22 \times \mathrm{SI}_{\mathrm{pH}}\right) \\
& +\left(0.28 \times \mathrm{SI}_{\mathrm{FCC}}\right) .
\end{aligned}
$$

DO (\% saturation):

$$
\begin{aligned}
& \mathrm{SI}_{\mathrm{DO}}=0.18+0.66 x, \quad 0-40 \% \text { saturation, } \\
& \mathrm{SI}_{\mathrm{DO}}=-13.5+1.17 x, \quad 40-100 \% \text { saturation, } \\
& \mathrm{SI}_{\mathrm{DO}}=263.34-0.62 x, \quad 100-140 \% \text { saturation. }
\end{aligned}
$$

$B O D_{5}(m g / L):$

$$
\begin{aligned}
& \mathrm{SI}_{\text {BOD } 5}=96.67-7 x, \quad 0-10, \\
& \mathrm{SI}_{\text {BOD5 }}=38.9-x, \quad 10-30, \\
& \mathrm{SI}_{\text {BOD5 }}=2, \quad>30
\end{aligned}
$$

pH:

$$
\begin{aligned}
& \mathrm{SI}_{\mathrm{pH}}=16.1+7.35 x, \quad 2-5, \\
& \mathrm{SI}_{\mathrm{pH}}=-142.67+33.5 x, \quad 5-7.3, \\
& \mathrm{SI}_{\mathrm{pH}}=316.96-29.85 x, \quad 7.3-10, \\
& \mathrm{SI}_{\mathrm{pH}}=96.17-8.0 x, \quad 10-12, \\
& \mathrm{SI}_{\mathrm{pH}}=0, \quad<2,>12 .
\end{aligned}
$$

FCC (counts/100 mL):

$$
\begin{aligned}
& \mathrm{SI}_{\mathrm{FCC}}=97.2-26.60 \log _{10} x, 1-10^{3}, \\
& \mathrm{SI}_{\mathrm{FCC}}=42.33-7.75 \log _{10} x, 10^{3}-10^{5}, \\
& \mathrm{SI}_{\mathrm{FCC}}=2, \quad>10^{5} .
\end{aligned}
$$

2.3.3. Minimal Water Quality Index [19]. $\mathrm{WQI}_{\min }$ is an index of arithmetic mean for normalized DO, Cond, and Turb; the normalized values are determined based on Table 2 with the index value categorized into five classes (Class I: 80-100; Class II: 60-80; Class III: 40-60; Class IV: 20-40; Class V: 0-20).

$$
\mathrm{WQI}_{\text {min }}=\frac{C_{\mathrm{DO}}+C_{\text {cond }}+C_{\text {turb }}}{3},
$$

where $C$ is the normalized value

2.3.4. Modified DOE-WQI. The modified DOE-WQI is calculated based on six variables, of which four are identical to that of DOE-WQI (DO, BOD, COD, and $\mathrm{NH}_{3}-\mathrm{N}$ ), whereas $\mathrm{pH}$ and TSS are replaced with FCC and Turb. This index was modified from DOE-WQI undergoing three important stages for selection of essential parameters, derivation of subindices, and assignment of suitable weightages as suggested by Sutadian et al. [20]. Considering the essential determinants, $\mathrm{pH}$ and TSS are replaced with FCC and Turb. The rationale of substituting TSS with turbidity is because the latter is able to measure the clarity of water in real time. On the other hand, $\mathrm{pH}$ is omitted for the reason that most rivers in Malaysia are almost consistent and near neutral and hence do not contribute significantly to the resulting index [11]. Fernandez et al. [21] compared 36 water quality indices revealing that $\mathrm{DO}, \mathrm{TS}, \mathrm{pH}, \mathrm{FCC}, \mathrm{BOD}$, total phosphorus, and nitrate are the most common parameters followed by Turb, Temp, and ammonia with similar importance. Although $\mathrm{pH}$ is obviously a parameter most conveniently measured for the calculation of WQI, Benvenuti et al. [22] asserted that $\mathrm{pH}$ and Temp are insignificant discriminants for the assessment of water quality. For subindices derivation, multiple functions were employed. The subindices of DO, turbidity, and FCC were assigned based on segmented nonlinear functions; this implies that a designated equation is applied over a specific range of the variable [2]. A nonlinear function was used for subindices conversion of BOD and $\mathrm{NH}_{3}-\mathrm{N}$ while COD was expressed as a linear function. The subindex functions of modified DOE-WQI are as follows. 
TABLE 3: The guidelines of water quality according to the National Water Quality Standards (NWQS) for Malaysia.

\begin{tabular}{|c|c|c|c|c|c|c|}
\hline \multirow{2}{*}{ Parameters } & \multicolumn{6}{|c|}{ Classes } \\
\hline & $\mathrm{I}$ & IIA & IIB & III & IV & $\mathrm{V}$ \\
\hline $\mathrm{pH}$ & $6.5-8.5$ & $6-9$ & $6-9$ & $5-9$ & $5-9$ & - \\
\hline Conductivity $(\mu \mathrm{S} / \mathrm{cm})$ & 1000 & 1000 & - & - & 6000 & - \\
\hline $\mathrm{TSS}(\mathrm{mg} / \mathrm{L})$ & 25 & 50 & 50 & 150 & 300 & 300 \\
\hline Turbidity (NTU) & 5 & 50 & 50 & - & - & - \\
\hline $\mathrm{DO}(\mathrm{mg} / \mathrm{L})$ & 7 & $5-7$ & $5-7$ & $3-5$ & $<3$ & $<1$ \\
\hline $\mathrm{BOD}(\mathrm{mg} / \mathrm{L})$ & 1 & 3 & 3 & 6 & 12 & $>12$ \\
\hline $\mathrm{COD}(\mathrm{mg} / \mathrm{L})$ & 10 & 25 & 25 & 50 & 100 & $>100$ \\
\hline $\mathrm{NH}_{3}-\mathrm{N}(\mathrm{mg} / \mathrm{L})$ & 0.1 & 0.3 & 0.3 & 0.9 & 2.7 & $>2.7$ \\
\hline FCC (counts/100 mL) & 10 & 100 & 400 & $5000\left(20,000^{*}\right)$ & $5000\left(20,000^{*}\right)$ & - \\
\hline
\end{tabular}

${ }^{*}$ Maximum not to be exceeded.

DO (\% saturation):

$$
\begin{aligned}
& \mathrm{SI}_{\mathrm{DO}}=0, \quad x \leq 13, x \geq 150, \\
& \mathrm{SI}_{\mathrm{DO}}=0.000004 x^{2}+1.264 x-16.44, \quad 13<x \leq 92, \\
& \mathrm{SI}_{\mathrm{DO}}=100, \quad 92<x \leq 120, \\
& \mathrm{SI}_{\mathrm{DO}}=-1.538 x+284.6, \quad 120<x<150 .
\end{aligned}
$$

$\mathrm{BOD}_{5}(m g / L):$

$$
\begin{aligned}
& \mathrm{SI}_{\text {BOD } 5}=0.098 x^{2}-6.96 x+100, \quad x \leq 20, \\
& \mathrm{SI}_{\text {BOD } 5}=0, \quad x>20 .
\end{aligned}
$$

COD $(m g / L):$

$$
\begin{aligned}
& \mathrm{SI}_{\mathrm{COD}}=-0.666 x+100, \quad x \leq 150, \\
& \mathrm{SI}_{\mathrm{COD}}=0, \quad x>150 .
\end{aligned}
$$

$\mathrm{NH}_{3}-\mathrm{N}(m g / L):$

$$
\begin{aligned}
& \mathrm{SI}_{\mathrm{NH} 3-\mathrm{N}}=0.966 x^{2}-24.83 x+100, \quad x \leq 5.0, \\
& \mathrm{SI}_{\mathrm{NH} 3-\mathrm{N}}=0, \quad x>5.0 .
\end{aligned}
$$

Turbidity (NTU):

$$
\begin{aligned}
& \mathrm{SI}_{\mathrm{TURB}}=-0.8 x+100, \quad x \leq 25, \\
& \mathrm{SI}_{\mathrm{TURB}}=-32.3 \ln (x)+185.4, \quad 25<x \leq 300, \\
& \mathrm{SI}_{\mathrm{TURB}}=0, \quad x>300 .
\end{aligned}
$$

\section{Fecal Coliform (counts/100 mL):}

$$
\begin{aligned}
& \mathrm{SI}_{\mathrm{FCC}}=-2 x+100, \quad x \leq 10, \\
& \mathrm{SI}_{\mathrm{FCC}}=-0.051 x+80.51, \quad 10<x \leq 400, \\
& \mathrm{SI}_{\mathrm{FCC}}=-15.3 \ln (x)+153.3, \quad 400<x \leq 20000, \\
& \mathrm{SI}_{\mathrm{FCC}}=0, \quad x>20000 .
\end{aligned}
$$

The modified index is adapted from the original WQI according to the National Water Quality Standards in Malaysia with five classes of water quality (as shown in Table 3 ). The original DOE-WQI was established by a team of multidisciplinary experts from universities [16]. In the original WQI, the subindex of DO is a nonsegmented function where DO greater than $92 \%$ is consistently assigned a value of 100 . Typically, DO over $90 \%$ saturation is an indication of good water quality, while below $50 \%$ it will cause negative effects on biological communities [23]. Under supersaturated water with $115-120 \%$ DO for a period of time, fish and invertebrates may develop gas bubble disease [24]. This condition is taken into account in the modified WQI. The subindices of BOD and $\mathrm{NH}_{3}-\mathrm{N}$ are expressed as nonlinear functions where a subindex value of zero is assigned when BOD and $\mathrm{NH}_{3}-\mathrm{N}$ are greater than 20 and $5 \mathrm{mg} / \mathrm{L}$, respectively. For COD on the other hand, the subindex is a linear function, differing from the original WQI of a combination of linear and nonlinear functions.

For relative weightage determination, a weight between 1 and 4 is assigned to each parameter; a higher value suggests greater importance. The relative weightage is calculated by dividing the assigned weight by the total weights. The sum of the weighted subindices is categorized into five classes to describe the water quality status (Class I: >91; Class II: 75-91; Class III: 57-75; Class IV 25-57; Class V: <25).

$$
\begin{aligned}
\text { Modified WQI }= & \left(0.20 \times \mathrm{SI}_{\mathrm{DO}}\right)+\left(0.18 \times \mathrm{SI}_{\mathrm{BOD}}\right) \\
& +\left(0.18 \times \mathrm{SI}_{\mathrm{COD}}\right) \\
& +\left(0.14 \times \mathrm{SI}_{\mathrm{NH}-\mathrm{N}}\right) \\
& +\left(0.15 \times \mathrm{SI}_{\mathrm{TURB}}\right) \\
& +\left(0.15 \times \mathrm{SI}_{\mathrm{FCC}}\right)
\end{aligned}
$$

2.4. Statistical Analyses and Map Representation. The water quality indices derived with different approaches were compared statistically using the paired $t$-test at significance level of 0.05 . Pearson's correlation was used to examine 
the relationships between different indices. The original and modified DOE-WQI were evaluated against a dataset simulated based on the National Water Quality Standards (NWQS) for Malaysia, serving as the benchmark. Note that the DOE-WQI is rooted on NWQS that categorizes water quality into five classes according to parameters as shown in Table 3. The dataset consists of 500 samples comprising 8 parameters (DO, BOD, COD, $\mathrm{NH}_{3}-\mathrm{N}$, Turb, FCC, TSS, and $\mathrm{pH})$. The simulated samples are generated according to the stipulated water quality of five classes in NWQS. For example, a sample of Class I shall exhibit $\mathrm{BOD}<1.0 \mathrm{mg} / \mathrm{L}$ according to NWQS. An algorithm is programmed to simulate a total of 100 samples with BOD $<1.0 \mathrm{mg} / \mathrm{L}$ according to uniform distribution; this is done in turn for the remaining classes and parameters, yielding a dataset with dimensions $500 \times 8$. The strategy of simulation is detailed in Sim et al. [25]. The river samples were classified based on Euclidean distance with the simulated data serving as the training set. The classification results were compared with the classes determined using the original and modified DOE-WQI. Principal Component Analysis (PCA) was used to illustrate the clustering pattern of the simulated samples according to classes. Prior to PCA, the data was standardized (mean centering and scaling by standard deviation) to ensure all variables are comparable. The statistical analyses were performed with Matlab 2013a. Quantum Geographic Information System (QGIS) was used to map the classes of water quality according to indexing methods for visualization.

\section{Results and Discussion}

3.1. Overall Water Quality. Table 4 summarizes the average water quality of 18 stations over three sampling campaigns in Dec 2015, Jan 2016, and Mar 2016. The measurements obtained are compared against the National Water Quality Standards (NWQS) for Malaysia to characterize the water quality status. Overall, $\mathrm{pH}$ is found to be between 6.95 and 7.58. As concluded by Al-Manun and Idris [11], $\mathrm{pH}$ is rather consistent for river water in Malaysia. For conductivity, the measurements vary between 47.67 and $4468 \mu \mathrm{S} / \mathrm{cm}$ with elevated readings recorded at ST15 and ST18 near the industrial area and ST16 and ST17 before and after Sarawak Barrage, respectively. This suggests input from industrial discharge and influence by barrage operation. Law et al. [26] monitored the salinity at 1.5 and $6 \mathrm{~km}$ upstream of Sarawak Barrage during flooding-in and flushing operations over 33 hours. The conductivity was found to fluctuate considerably between 0 and $24000 \mu \mathrm{S} / \mathrm{cm}(14.5 \mathrm{ppt})$ at $1.5 \mathrm{~km}$ upstream but was negligibly low at the station of $6 \mathrm{~km}$ $(0-1000 \mu \mathrm{S} / \mathrm{cm}$ or $<0.5 \mathrm{ppt})$. During sampling in Dec 2015 and Jan 2016, the conductivity was seen to be elevated possibly due to the extended dry period and low flow condition. The turbidity varies between 21.14 and 208.71 NTU, with the highest measurement recorded at ST16, after barrage. Relatively turbid water is also recorded at ST6-ST8 near the confluence of Sarawak Kiri and Sarawak Kanan River. The DO level lies between 1.98 and $5.18 \mathrm{mg} / \mathrm{L}$. At ST11-ST13, located at the highly populated Maong River catchment, the DO is particularly low, likely associated with the input of untreated domestic waste. The DO at ST1-ST10 is noticeably higher than that at ST11-ST18 as the upper reaches of Sarawak River (situated at the steep terrain) are typically narrower and shallower and hence the water is relatively fast flowing facilitating higher DO [27]. Generally, DO is rated between Classes III and IV according to NWQS where extensive treatment is required. The TSS ranges between 20.71 and $227.96 \mathrm{mg} / \mathrm{L}$ (Class I to Class V) with ST16 recording the highest concentration, corresponding to the measurement of turbidity. The BOD level is typically between 1.42 and $2.53 \mathrm{mg} / \mathrm{L}$ while COD ranges between 0.79 and $17.73 \mathrm{mg} / \mathrm{L}$. $\mathrm{NH}_{3}-\mathrm{N}$ is generally present in traces across all stations $(<0.2 \mathrm{mg} / \mathrm{L})$ except in ST10-ST13 with a concentration above $1.4 \mathrm{mg} / \mathrm{L}$ suggesting input of sewage effluent. Fecal coliform count varies extensively from 6500 to $94,805 \mathrm{CFU} / 100 \mathrm{~mL}$ with various stations recording measurements above the maximum NWQS limit of 20,000 counts $/ 100 \mathrm{~mL}$, suggesting microbiological contamination in water. Povlsen [27] likewise observed poor FCC of more than 16,000 counts/100 mL in catchments of Sarawak River and its tributaries, postulating discharge of untreated sewage effluents from inefficient septic tanks.

3.2. Assessment of Water Quality Index. The physicochemical DOE-WQI is compared with the River Ganga Index, $\mathrm{WQI}_{\text {min }}$, and the modified WQI. Table 5 shows the water quality index of 18 stations over three sampling campaigns with the classes assigned according to the four indexing methods. The WQIs derived using different methods are significantly correlated $(p<0.05)$, suggesting that these indices exhibit corresponding behavior on the water quality (Table 6). Essentially, the water quality is categorized between Classes II and III using the original DOE-WQI although the index attained in Jan (62-82) and Mar 2016 (59-87) is significantly lower than that recorded in Dec $2015(62-94)(p<0.05)$. With the modified strategy, the water quality is rated between Classes II and IV with a similar observation of poorer water quality in Jan and Mar 2016 (Dec: 50-80; Jan: 52-75; Mar: 48-73). It is also found that the modified index consistently assigns samples to a lower class compared to the original DOE-WQI with a significant difference $(p<0.05)$.

Table 7 shows the cumulative sum of weighted subindices, calculated for the average samples of three samplings, using the original and modified DOE-WQI. As observed, the cumulative sums attained using both methods are comparable when 5 variables are considered (DO, BOD, COD, $\mathrm{NH}_{3}-\mathrm{N}$, and TSS/Turb); however, when FCC replaces $\mathrm{pH}$, there is a marked difference in the aggregated values. The modified index only experiences an increment of 2 points upon addition of the weighted $\mathrm{SI}_{\mathrm{FCC}}$ while the original DOEWQI encounters an addition of 12 points with inclusion of SIpH. This implies considerable influence of FCC over the resultant index. Benvenuti et al. [22] evaluated the water quality of Sinos River Basin in South Brazil using three different indexing methods. It was concluded from the results that an index that comprises significant discriminants with adequate weightage is essential for a more representative evaluation of water quality. 


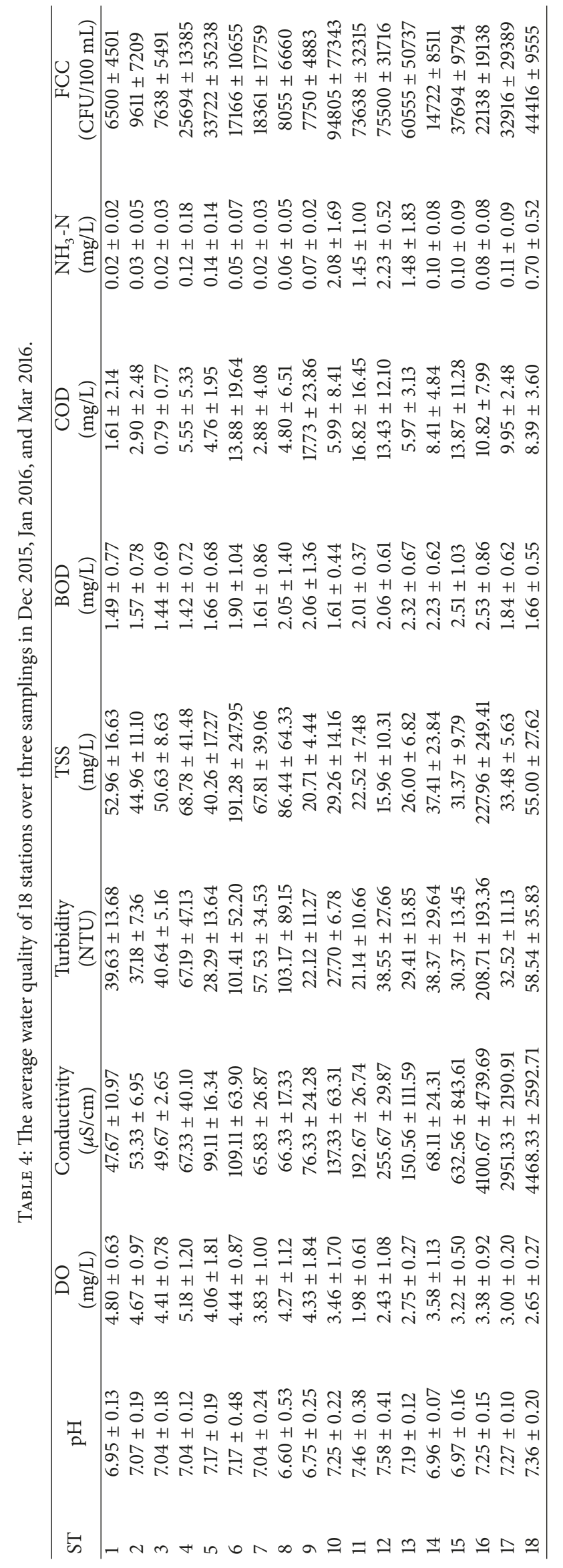




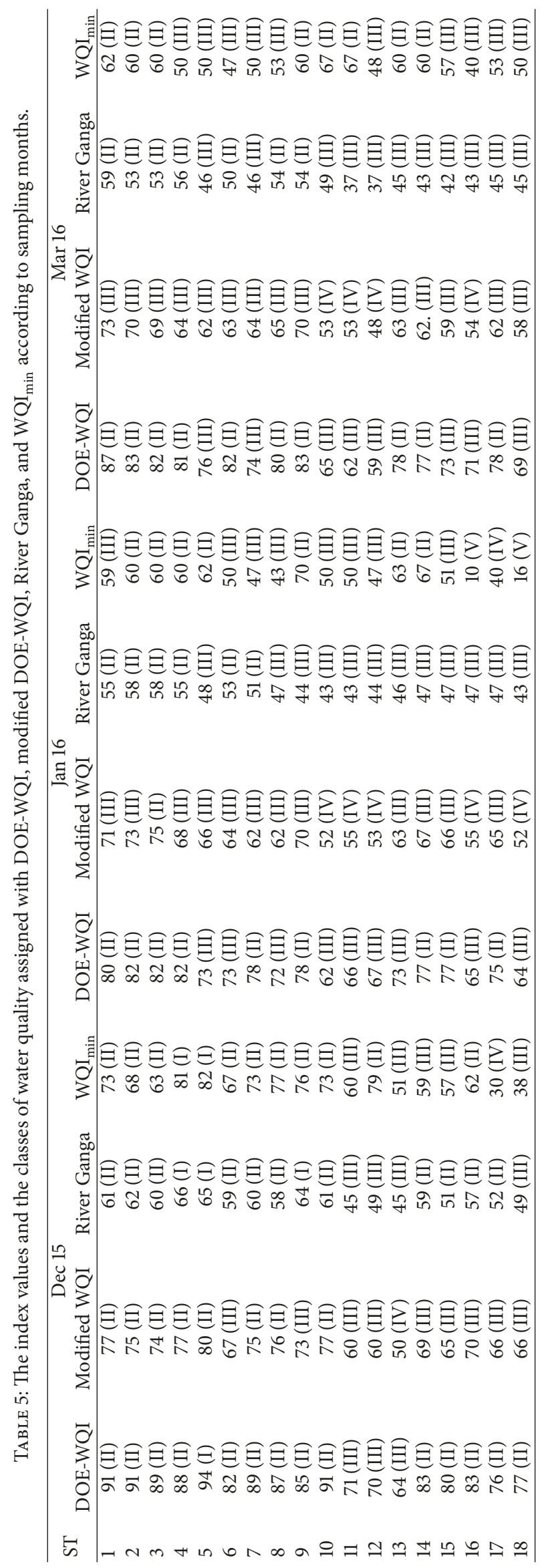



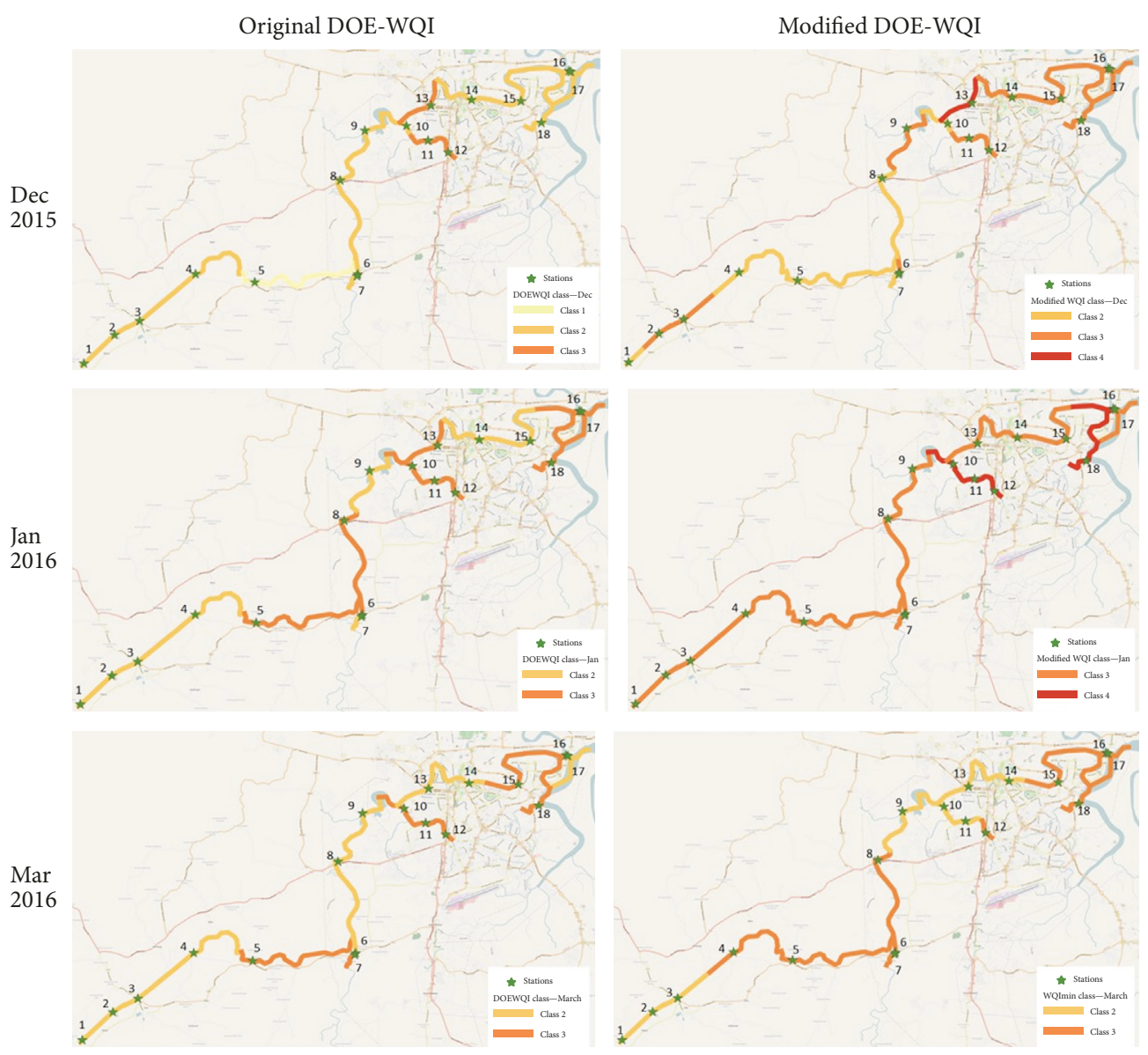

FIGURE 2: Map representations of the water quality of the Sarawak River and its tributaries.

TABLE 6: Correlation coefficients ( $R$ values) between the four indexing methods.

\begin{tabular}{lcccc}
\hline & DOE-WQI & Modified WQI & River Ganga & WQI $_{\text {min }}$ \\
\hline DOE-WQI & 1 & & & \\
Modified WQI & 0.94 & 1 & & \\
River Ganga & 0.87 & 0.86 & 1 & \\
WQI $_{\text {min }}$ & 0.56 & 0.60 & 0.52 & 1 \\
\hline
\end{tabular}

According to the River Ganga Index, the river is assigned to Classes II-IV (Dec: 45-66; Jan: 43-58; Mar: 37-59) with a similar observation of reducing water quality in Jan and Mar 2016. Many stations are rated as polluted to heavily polluted with an index value of $<50$. Like the modified WQI, the high FCC values contribute to small weighted subindices of 1-7 points to the overall aggregated value. Despite the reduced number of parameters used in the River Ganga Index, the index values attained remain responsive to the changes in water quality.

The three-parameter $\mathrm{WQI}_{\min }$ is an index of arithmetic mean for normalized DO, Turb, and Cond. This simple index was reported to be comparable to two other indices of
20 parameters for the assessment of water body under the influence of industrial discharge [28]; nonetheless, there is a tendency of overestimation as the parameters are assigned with similar weightage $[29,30]$. As observed, water quality depicted with $\mathrm{WQI}_{\min }$ covers a wide spectrum from Class I to Class $\mathrm{V}$ with index values ranging between 10 and 82 . The index similarly indicates poorer water quality conditions in Jan and Mar 2016, with Stations 16-18 (near industrial area and barrage) corresponding to lower index values due to high turbidity and conductivity. This suggests that $\mathrm{WQI}_{\min }$ is suitable for probing contamination from industrial discharge; nonetheless, some contradicting values are detected. For example, the water quality at ST4, collected in Dec 2015, was assigned a score of 81 indicative of good water quality, but it does not reflect the problem attributed to FCC with a measurement of 40,000 counts $/ 100 \mathrm{~mL}$. This misleading score is a typical consequence of a situation when the parameters chosen for WQI calculation do not represent the environmental stress.

Water quality of the 18 stations determined with the original and modified DOE-WQI is mapped with QGIS for better visualization and comparison (Figure 2). The water quality is represented with different colors according to classes (darker color indicates poorer water quality). As demonstrated, the 
TABLE 7: The cumulative weighted subindices for the original and modified DOE-WQI.

\begin{tabular}{|c|c|c|c|c|c|c|}
\hline \multirow{2}{*}{ Weighted subindices } & \multicolumn{2}{|c|}{ Dec } & \multicolumn{2}{|c|}{ Jan } & \multicolumn{2}{|c|}{ Mar } \\
\hline & Original & Modified & Original & Modified & Original & Modified \\
\hline DO & 14.9 & 12.9 & 7.6 & 7.3 & 7.6 & 7.3 \\
\hline $\mathrm{DO}+\mathrm{BOD}$ & 32.8 & 28.3 & 25.7 & 23.9 & 25.8 & 24.2 \\
\hline $\mathrm{DO}+\mathrm{BOD}+\mathrm{COD}$ & 46.3 & 44.8 & 40.6 & 39.5 & 40.0 & 39.4 \\
\hline $\mathrm{DO}+\mathrm{BOD}+\mathrm{COD}+\mathrm{NH}_{3}-\mathrm{N}$ & 58.5 & 58.3 & 52.0 & 52.6 & 52.5 & 52.8 \\
\hline $\begin{array}{l}\mathrm{DO}+\mathrm{BOD}+\mathrm{COD}+\mathrm{NH}_{3}-\mathrm{N}+\mathrm{TSS} \\
(\text { original } / \text { Turb (modified) }\end{array}$ & 71.4 & 68.9 & 61.8 & 61.5 & 63.6 & 62.1 \\
\hline $\begin{array}{l}\mathrm{DO}+\mathrm{BOD}+\mathrm{COD}+\mathrm{NH}_{3}-\mathrm{N}+\mathrm{TSS} \\
\text { (original)/Turb (modified) }+\mathrm{pH} \\
\text { (original)/FCC (modified) }\end{array}$ & 83.2 & 70.1 & 73.5 & 63.7 & 75.3 & 62.5 \\
\hline
\end{tabular}

rivers are characterized between Class I and Class III with the original DOE-WQI over three samplings; nonetheless, with the modified strategy, it is found that several stretches of the rivers are categorized in Class IV with most stations assigned to Class III. This is similarly observed with the River Ganga Index (maps are not shown).

3.3. Classification with Euclidean Distance. To assess the efficiency of DOE-WQI, training data simulated according to the guidelines of NWQS is used as the benchmark. The simulated data comprising eight variables (DO, BOD, COD, TSS, $\mathrm{pH}, \mathrm{NH}_{3}-\mathrm{N}, \mathrm{FCC}$, and Turb) was subjected to PCA to reveal the underlying clustering pattern. Figure 3 shows the scores plot of PC2 versus PC1; samples from different classes are noticeably distinguishable, indicative of their distinctive characteristics. The simulated data was used as the training samples for classification of the river water based on Euclidean distance. Table 8 summarizes water quality of the 18 stations classified based on Euclidean distance and the indexing methods. Most stations are categorized in Classes I and II according to Euclidean distance (based on 6 physicochemical parameters), matching the classes determined with DOE-WQI. Some minor discrepancies are detected; for example, a sample with a score of 81 is denoted as Class II using DOE-WQI but is appointed to Class III with Euclidean distance. This is possibly attributed to inconsistencies in the classification criteria. With the inclusion of FCC, the samples are mostly classified between Classes III and IV based on Euclidean distance; this corresponds better to the modified DOE-WQI. Evidently, DOE-WQI classifies water accordingly but did not pick up the environmental stress caused by the microbiological parameter. This signifies the pitfall of the indexing method when an important discriminant is not included.

\section{Conclusions}

Results show that the Sarawak River and its tributaries are generally rich in FCC with elevated conductivity identified at stations near industrial areas and barrage. The water quality is very much affected by the weather condition and the adjacent

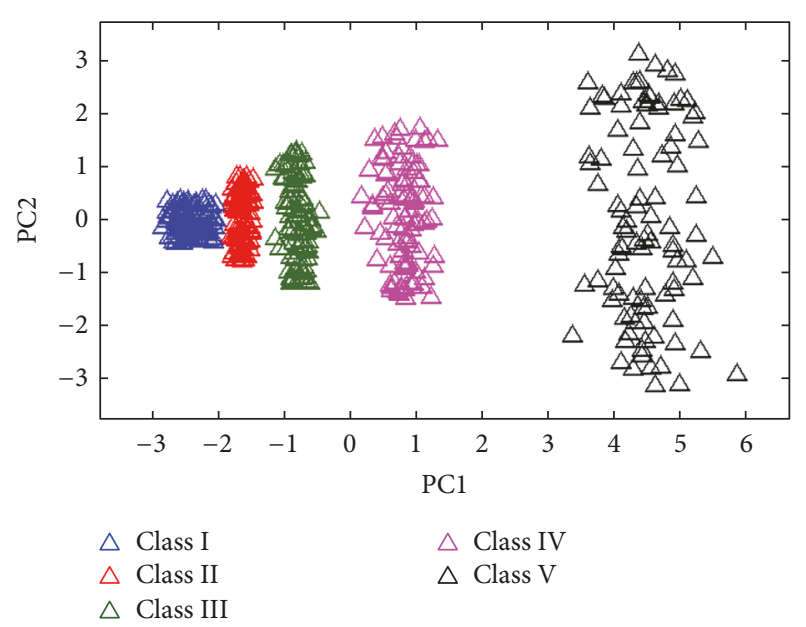

FIGURE 3: The scores plot of training data with five classes comprising eight parameters (DO, BOD, COD, TSS, $\mathrm{pH}, \mathrm{NH}_{3}-\mathrm{N}, \mathrm{FCC}$, and Turb).

land use activities. The water quality indices evaluated exhibit a corresponding behavior; nonetheless, it is found that the existing DOE-WQI tends to rate the river at better water quality than its actual condition as the deteriorating FCC is not included in the index. Assessment with Euclidean distance confirms that the existing DOE-WQI does not carry sufficient information to provide a representative assessment of water quality. The findings demonstrate that tropical rivers in this region are challenged with deteriorated water quality associated with domestic sewage; hence, the microbiological parameter is a crucial discriminant for the calculation of WQI. This paper demonstrates the shortcomings of a physicochemical indexing method when a significant discriminating variable is not taken into consideration.

\section{Conflicts of Interest}

The authors declare that there are no conflicts of interest regarding the publication of this article. 


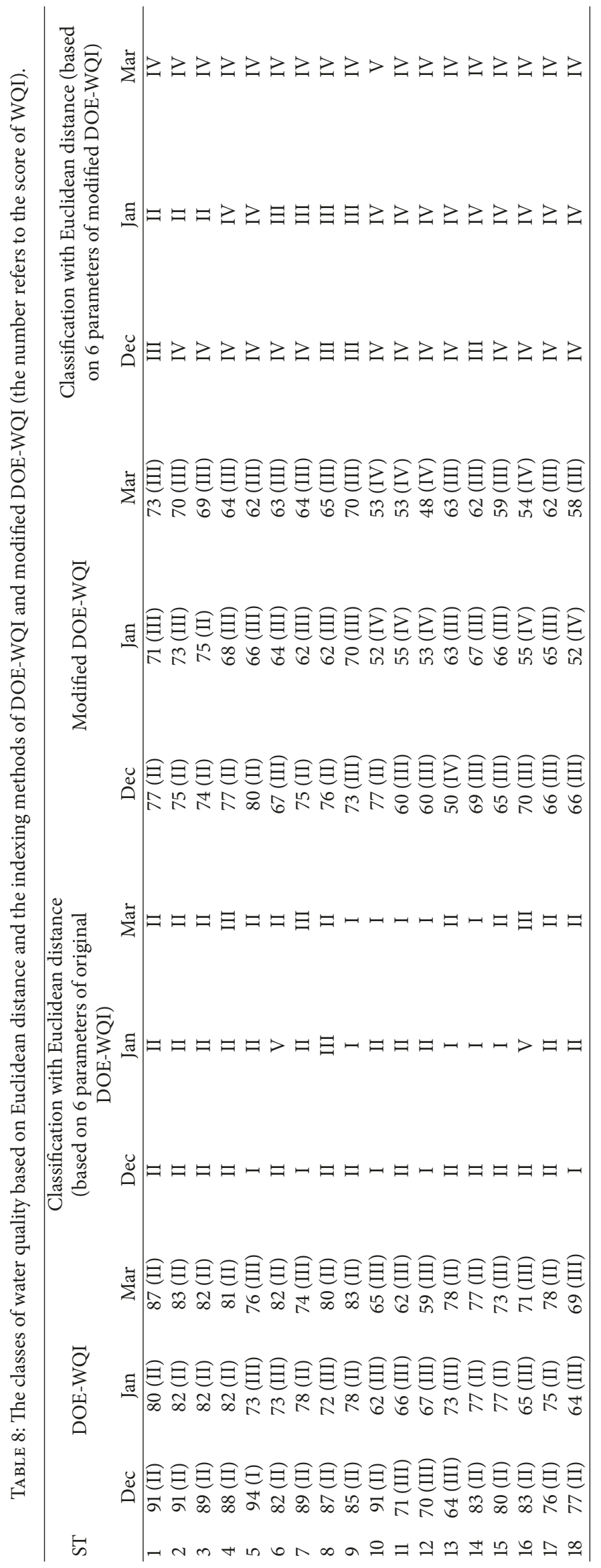




\section{Acknowledgments}

The authors would like to thank the Ministry of Higher Education, Malaysia, for funding this project (ERGS/STWN (01)1015/2013(12)).

\section{References}

[1] DOE (Department of Environment) (2012), Malaysia: Environmental quality report 2012, Ministry of Science, Technology and the Environment, Putrajaya, Malaysia, 2012.

[2] T. Abbasi and S. A. Abbasi, Water Quality Indices, Elsevier, Oxford, UK, 2012.

[3] G. Singh and R. Kamal, "Application of water quality index for assessment of surface water quality status in Goa," Current World Environment, vol. 9, no. 3, pp. 994-1000, 2014.

[4] C. G. Cude, "Oregon water quality index: A tool for evaluating water quality management effectiveness," Journal of the American Water Resources Association, vol. 37, no. 1, pp. 125-137, 2001.

[5] M. W. Gitau, J. Chen, and Z. Ma, "Water quality indices as tools for decision making and management," Water Resource Management, vol. 30, no. 8, pp. 2591-2610, 2016.

[6] A. Said, D. K. Stevens, and G. Sehlke, "An innovative index for evaluating water quality in streams," Journal of Environmental Management, vol. 34, no. 3, pp. 406-414, 2004.

[7] E. D. Ongley, "Modernization of water quality programs in developing countries: Issues of relevancy and cost efficiency," Water Quality International, vol. 3, no. 4, pp. 37-42, 1998.

[8] Environment Protection Department of Hong Kong (2013), "Water: River water quality monitoring in Hong Kong," http://www.epd.gov.hk/epd/mobile/english/environmentinhk/ water/river_quality/rwq_monitoring.html.

[9] F. D. S. Simões, A. B. Moreira, M. C. Bisinoti, S. M. N. Gimenez, and M. J. S. Yabe, "Water quality index as a simple indicator of aquaculture effects on aquatic bodies," Ecological Indicators, vol. 8, no. 5, pp. 476-484, 2008.

[10] A. A. Mamun and Z. Zainudin, "Sustainable river water quality management in Malaysia," IIUM Engineering Journal, vol. 14, no. 1, pp. 29-42, 2013.

[11] A. Al-Manun and A. Idris, "Revised water quality indices for the protection of rivers in Malaysia," in Proceeding of the 12th International Water Technology Conference, Alexandria, Egypt, 2008.

[12] F. Al-Badaii, M. Shuhaimi-Othman, and M. B. Gasim, "Water quality assessment of the Semenyih River, Selangor, Malaysia," Journal of Chemistry, vol. 2013, Article ID 871056, 10 pages, 2013.

[13] F. Othman, M. S. U. Chowdhury, and N. Sakai, "Assessment of microorganism pollution of Selangor River, Malaysia," International Journal of Advances in Agricultural and Environmental Engineering, vol. 1, no. 2, pp. 203-207, 2014.

[14] M. R. Nurul Ruhayu, J. A. Yii, and Y. Khairun, "Detection or river pollution using water quality index: A case study of tropical rivers in Penang Island," Open Access Library Journal, vol. 2, no. 3, Article no 68088, 8 pages, 2015.

[15] D. Kozaki, M. Hasbi bin Ab. Rahim, W. Mohd Faizal bin Wan Ishak et al., "Assessment of the river water pollution levels in Kuantan, Malaysia, using ion-exclusion chromatographic data, water quality indices, and land usage patterns," Air, Soil and Water Research, vol. 9, 11 pages, 2016.

[16] I. Naubi, N. H. Zardari, S. M. Shirazi, N. F. B. Ibrahim, and L. Baloo, "Effectiveness of water quality index for monitoring
Malaysian river water quality," Polish Journal of Environmental Studies, vol. 25, no. 1, pp. 231-239, 2016.

[17] APHA (American Public Health Association) (2005), Standard Methods for the Examination of Water and Wastewater, American Public Health Association/American Water Works Association/Water Environment Federation, Wash, USA, 20th edition, 2005.

[18] R. Bhutiani, D. R. Khanna, D. B. Kulkarni, and M. Ruhela, "Assessment of Ganga river ecosystem at Haridwar, Uttarakhand, India with reference to water quality indices," Applied Water Science, vol. 6, no. 2, pp. 107-113, 2016.

[19] S. F. Pesce and D. A. Wunderlin, "Use of water quality indices to verify the impact of Cordoba City (Argentina) on Suquia River," Water Research, vol. 34, no. 11, pp. 2915-2926, 2000.

[20] A. D. H. Sutadian, N. Muttil, A. G. O. Yilmaz, and B. J. C. Perera, "Development of river water quality indices-a review," Environmental Modeling \& Assessment, vol. 188, no. 1, p. 58, 2016.

[21] N. Fernandez, A. Ramirez, and F. Solano, "Physico-chemical water quality indices a comparative review," Revisa Bistua, pp. 19-30, 2004.

[22] T. Benvenuti, M. A. Kieling-Rubio, C. R. Klauck, and M. A. S. Rodrigues, "Evaluation of water quality at the source of streams of the Sinos River Basin, Southern Brazil," Brazilian Journal of Biology, vol. 75, no. 2, pp. S98-S104, 2015.

[23] G. Srivastava and P. Kumar, "Water quality index with missing parameters," International Journal of Research in Engineering and Technology, vol. 2, no. 1, pp. 609-614, 2013.

[24] D. E. Weitkamp and M. Katz, "A review of dissolved gas supersaturation literature," Transactions of the American Fisheries Society, vol. 109, no. 6, pp. 659-702, 1980.

[25] S. F. Sim, T. Y. Ling, S. Lau, and M. Z. Jaafar, "A novel computeraided multivariate water quality index," Environmental Modeling \& Assessment, vol. 187, no. 4, pp. 1-11, 2015.

[26] I. N. Law, Y. W. Oon, P. L. Law, and F. W. L. Kho, "Impacts of barrage flushing and flooding-in operations on saline intrusion upstream," UNIMAS e-Journal of Civil Engineering, vol. 2, no. 1, pp. 18-24, 2011.

[27] E. Povlsen, "Environment of Sungai Sarawak: relationships between city and river. river quality baseline study," Tech Rep. No. SUD-02-25, UM Colour Printing Company, Sarawak, Malaysia, 2001.

[28] R. Abrahão, M. Carvalho, W. R. Da Silva Jr., T. T. V. Machado, C. L. M. Gadelha, and M. I. M. Hernandez, "Use of index analysis to evaluate the water quality of a stream receiving industrial effluents," Water SA, vol. 33, no. 4, pp. 459-465, 2007.

[29] P. R. Kannel, S. Lee, Y.-S. Lee, S. R. Kanel, and S. P. Khan, "Application of water quality indices and dissolved oxygen as indicators for river water classification and urban impact assessment," Environmental Modeling \& Assessment, vol. 132, no. 1-3, pp. 93110, 2007.

[30] I. M. M. Rahman, M. M. Islam, M. M. Hossain et al., "Stagnant surface water bodies (SSWBs) as an alternative water resource for the Chittagong metropolitan area of Bangladesh: physicochemical characterization in terms of water quality indices," Environmental Modeling \& Assessment, vol. 173, no. 1-4, pp. 669684, 2011. 

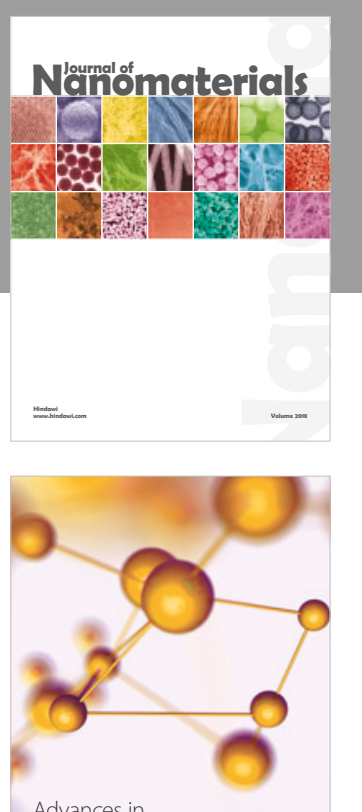

Physical Chemistry
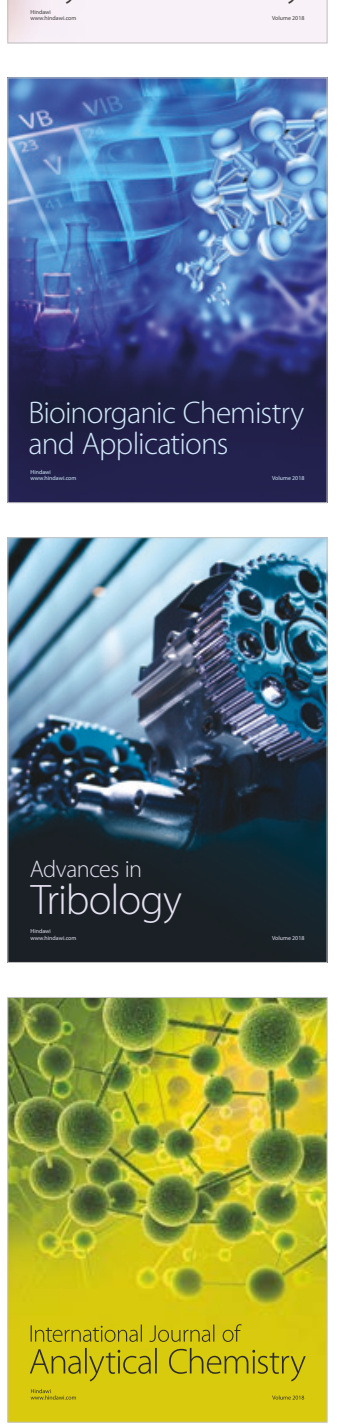

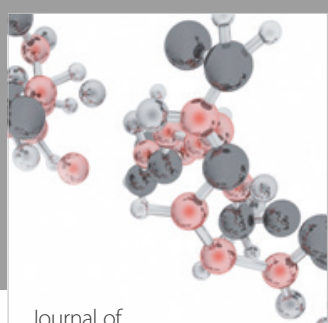

Analytical Methods

in Chemistry

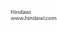

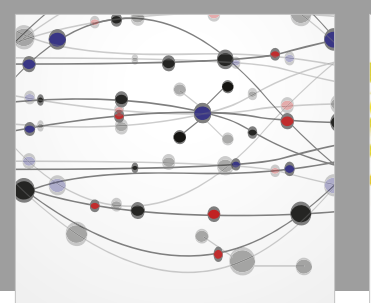

The Scientific World Journal

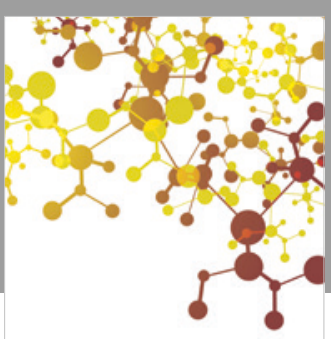

Journal of

Applied Chemistry
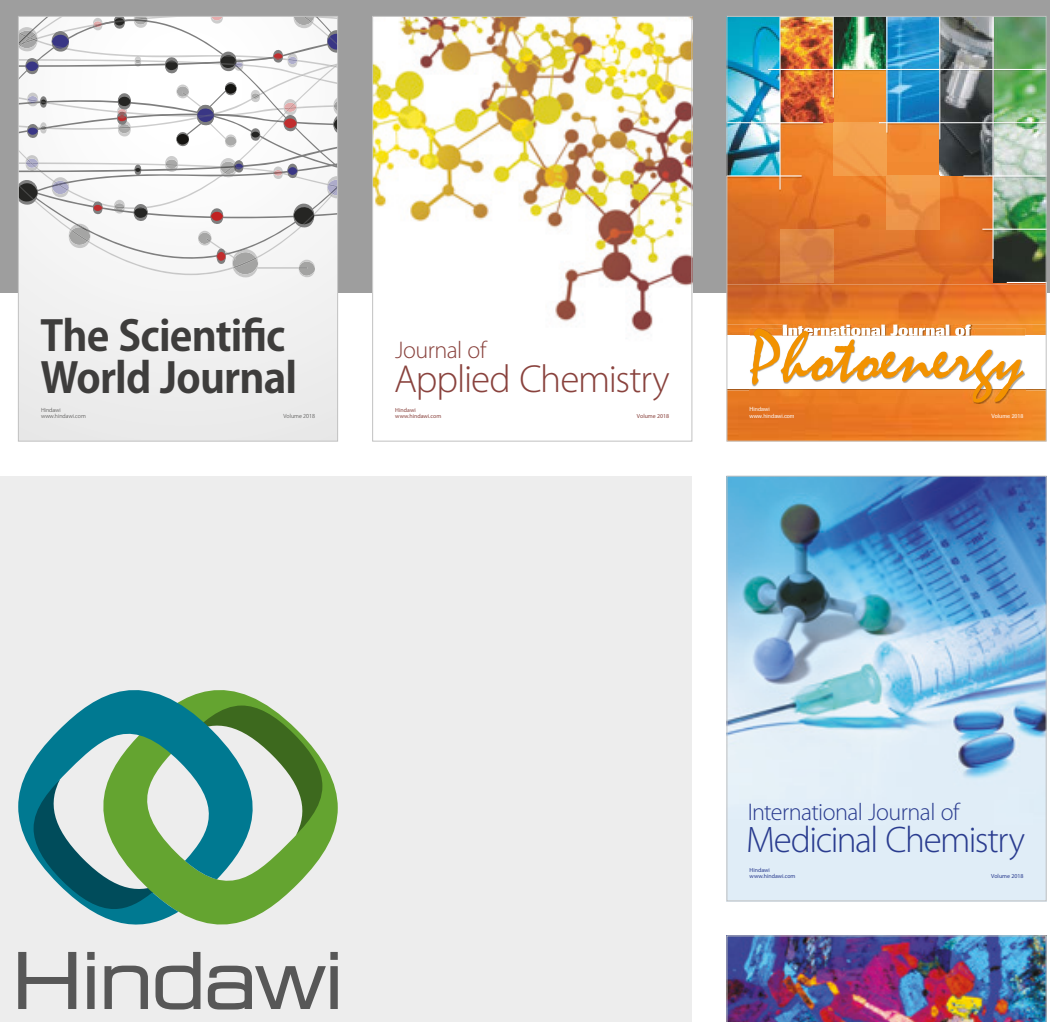

Submit your manuscripts at

www.hindawi.com
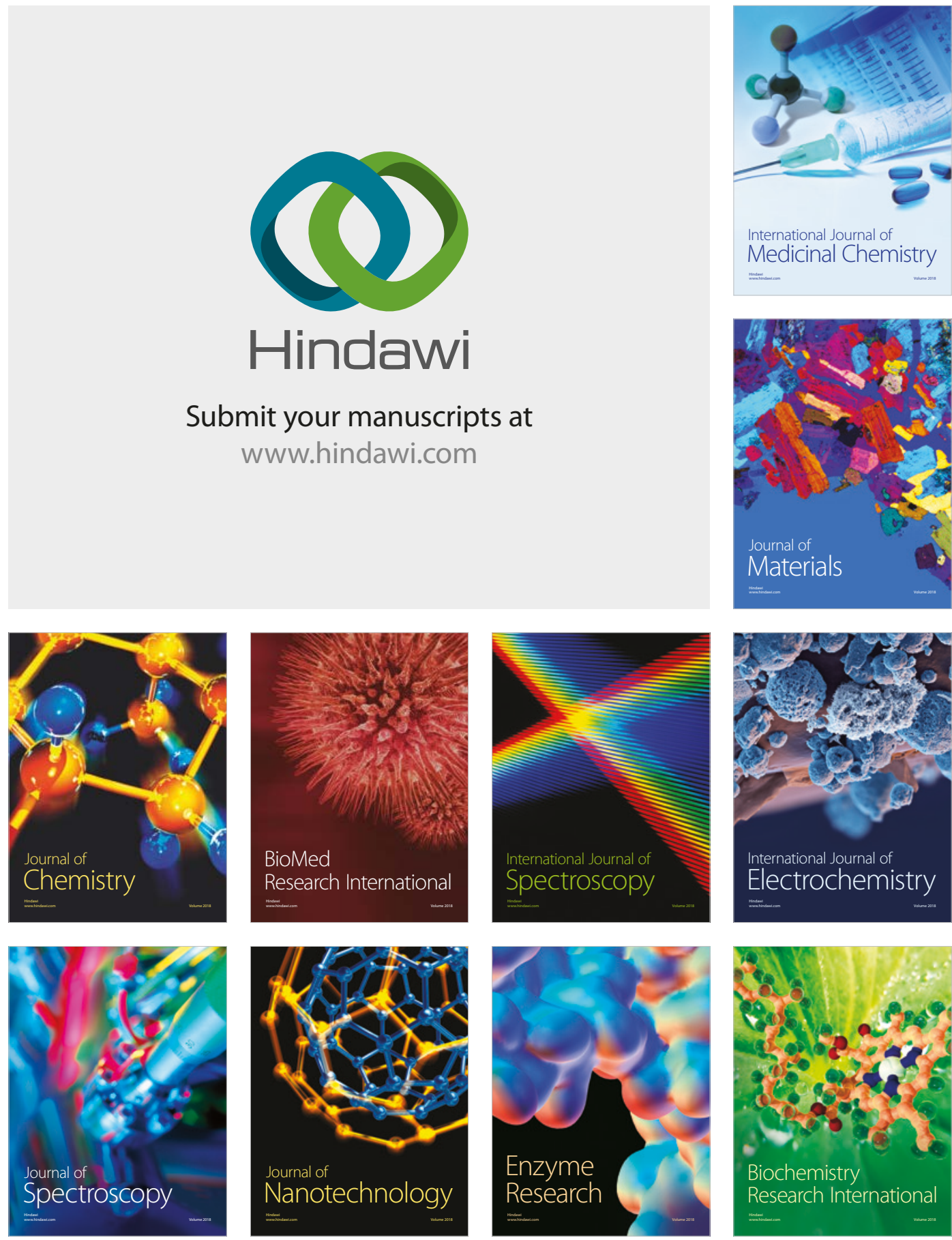
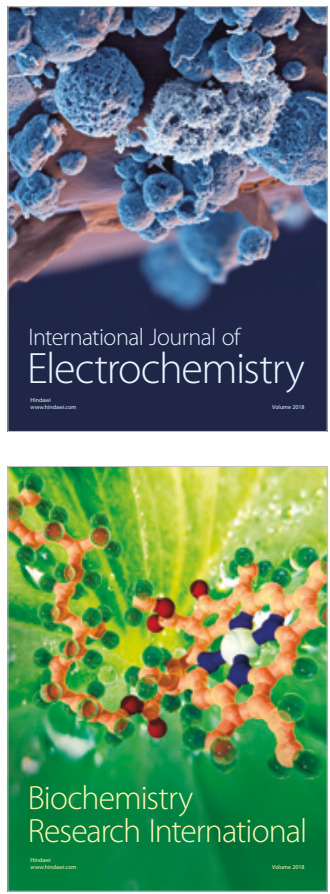